\title{
POLITICAL-ECONOMIC TRANSITION IN GEORGIA AND ITS IMPLICATIONS FOR TOURISM IN SVANETI
}

\author{
Frieder Voll, University of Applied Sciences HTW Chur, Switzerland \\ Jan Mosedale, University of Applied Sciences HTW Chur, Switzerland
}

\begin{abstract}
Private tourism entrepreneurship relies on special knowledge of the service sector with a strong focus on individual action and a general service mentality. The organization and regulation of tourism in post-socialist European countries experienced a shift from being state-driven to being determined by individual entrepreneurs. Yet in some cases, the adoption of the new entrepreneurial business principles is contested by different cultural understandings of how tourism should be 'produced'. With examples from the Caucasus Mountains in Georgia (Svaneti) we will demonstrate that these different understandings can play a major role in creating barriers for developing community-based tourism. Shortly after the transition to the market economy, a number of different small-scale, community-based tourism projects emerged, with individual entrepreneurship contesting the traditional values of hospitality in these regions (predominantly based on religious and 'tribal' values and norms rather than purely on entrepreneurial values). The methods used for this preliminary study of post-socialist tourism development included a short-term, mobile ethnography consisting of semi-structured interviews of tourism producers in the region, participant observation, as well as mapping occupancy of buildings according to unoccupied, agriculture and agritourism and second homes categories based on the condition of the gardens. Further changes in the political-economic framework have now shifted the focus towards larger-scale tourism developments supported by public-private partnerships. This paper analyses the impacts of these political-economic changes on the development of community-based tourism in Svaneti and explores in particular the friction between collective traditions and individual entrepreneurship in the experience economy of transition countries and its relationship with regional economic growth and rural depopulation.
\end{abstract}

Keywords: Tourism, Post-socialism, Transition, Individual entrepreneurship, Hospitality, Georgia

\section{POLITIČKO-EKONOMSKA TRANZICIJA U GRUZIJI I NJENE IMPLIKACIJE NA TURIZAM U SVANETIJU}

\section{Sažetak}

Privatno preduzetništvo u turizmu se oslanja na posebno znanje u uslužnom sektoru, sa snažnim fokusom na individualnu aktivnost i uslužni mentalitet uopšte. Organizacija i regulacija turizma u postsocijalističkim evropskim zemljama su pretrpele prelaz od državnih do onih određenih od strane individualnih preduzetnika. Ipak, u nekim slučajevima, usvajanje novih preduzetničkih poslovnih principa je osporeno različitim kulturnim poimanjima toga kako treba „proizvoditi” turizam. Koristeći primere sa planine Kavkaz u Gruziji (Svaneti) pokazaćemo kako ova različita poimanja mogu igrati veliku ulogu u stvaranju barijera za razvoj turizma podržanog od strane zajednice. Nedugo po prelasku na tržišnu ekonomiju pojavio se izvestan broj raznih malih turističkih projekata podržanih od strane 
zajednice, u kojima je individualno preduzetništvo počelo da konkuriše tradicionalnim vrednostima ugostiteljstva u ovim krajevima (uglavnom zasnovanim na verskim i „plemenskim” vrednostima i normama, pre nego na čisto preduzetničkim). Metodi korišćeni za ovu preliminarnu studiju o postsocijalističkom razvoju turizma uključuju kratkotrajnu mobilnu etnografiju, koja se sastojala od polustruktuiranog intervjua turističkih ponuđača u regionu, opažanja učesnika, kao i mapiranja useljenosti objekata - od neuseljenih, preko poljoprivrednih i agrourističkih do kuća druge kategorije, prema stanju uređenosti dvorišta. Dalje izmene u političko-ekonomskom okviru su u međuvremenu pomerile fokus ka širem turističkom razvoju, uz podršku javno-privatnih partnerstava. Ovaj rad analizira uticaje tih političko-ekonomskih promena na razvoj turizma podržanog od strane zajednice u Svanetiju i naročito istražuje frikciju između kolektivnih tradicija i individualnog preduzetništvau ekonomiji doživljaja u zemljama u razvoju, kao i njihov odnos prema regionalnom ekonomskom rastu i ruralnoj depopulaciji.

Ključne reči: turizam, postsocijalizam, tranzicija, individualno preduzetništvo, ugostiteljstvo, Gruzija

TIMS Acta (2015) 9, 91-103

\section{Introduction}

The civil resistance to state-socialism in Eastern Europe in 1989 marked a key period in the process of the eventual dissolution of the socialist planned economies and the democratization of former state-socialist countries. The comprehensive change in the regime of accumulation in former Eastern Europe socialist countries and the Soviet Union resulted in new sets of formal and informal norms, rules, codes, social practices and institutions (modes of regulation) to stabilize and guarantee the continued reproduction of the new market economies. This comprehensive transition from statesocialism offered political economists an opportunity to research the transition process, in particular with a view to examine the restructuring of the modes of regulation.

While the political-economic change seemingly presented governments and entrepreneurs with a blank slate for restructuring (e.g. institutions, regulations and laws) and thus opportunities for path creation, the transition was also path dependent, in that opportunities were to some extent dependent on the political-economic trajectory of the past (see Hall, 2004). In the case of the former Czechoslovakia, for example, path dependence was linked to the continued importance of social relations and conflicts remaining from the state socialist period (Williams \& Balàž, 2002). Even though the regime of accumulation collapsed, the pace of transition has resulted in limited time for the social and political co-evolution of institutions (Williams
\& Balàž, 2002). The development of new institutional arrangements (path creation) was therefore also pathdependentand open to continued evolution over time. These continued transitional evolutions in the formerly socialist statesare context specific and have not followed a unified direction, nor are these developments spatially even (Tickle, 2000). Instead, the transition economies are a bricolage constituted to varying degrees of different types of diverse economic practices (Smith \& Stenning, 2006) such as market, collective and informal practices: "It is through a political and an economic bricolage that new institutions and new practices emerge" (Stark \& Bruszt, 1998). Economic actors, such as entrepreneurs, households or communities find their own strategies within the structures of the political economic system. The economy is enacted, (re)produced and potentially transformed in everyday economic practices and thus is constituted of a multitude of practices that fall within the continuum of capitalist-non-capitalist, formal-informal; market-non-market, collective-individual practices (Mosedale, 2011).

There has been some early engagement with these political-economic developments and their impact on tourism (see for example Hall, 1991, 1998; Jaakson, 1996; Worthington, 2001; Williams, \& Balàž 2000), yet there is a need to continue the analysis in relation to the continuous political-economic developments in the region. Although there is ample literature on the early post-socialist transition of former Soviet states, this period of political-economic change still has ramifications 
on current tourism development in the regions (in terms of path dependence and path creation) and is worthy of further analysis. The effects of the varied shifts from a state-socialist to a predominantly capitalist economy on tourism development has received relatively little attention. This paper therefore explores two interrelated aspects of tourism in transition countries through a case study of the Svaneti region in Georgia: the relationship between individual and collective entrepreneurship and the commodification of traditional values, in this case hospitality.

Williams \& Baláž (2001) focus on the increasingly unequal access to tourism after 1998 due to the unequal distribution of income and of benefits emanating from private property rights, but also due to the discontinuation of some forms of collective provisioning of tourism (e.g. enterprise-owned holiday centres). This paper aims to explore the relationship between collective and individual entrepreneurship as two different ways to organise the commodification of tourism (see for example Mosedale, 2006). The results of this exploratory study reveal the existence of varied forms of entrepreneurship, 'entrepreneurial pathways' (Stoica, 2004) and 'entrepreneurial cultures' (Wyrwich, 2012) in transition countries. For instance, some studies (Kornai, 1992; Wyrwich, 2012) have shown that entrepreneurialism did exist in socialist systems (albeit very limited and institutionally constrained) and that these entrepreneurs helped kick start the growth of entrepreneurship during the transition process. This paper, however, explores the residual culture of collective provisioning in centrally-planned economies with the new notions of individual entrepreneurship in market economies. In the case study of Svaneti, a region of Georgia, it is evident that individual entrepreneurship (especially with support from external investment) may come into conflict with more collective forms of entrepreneurship as experienced in community-based tourism projects.

Within this context of post-socialist entrepreneurship in tourism, it is also important to briefly discuss hospitality as a fundamental attribute of Georgian society (Curro, 2014). Hospitality is regulated via social norms and values emanating from religious and tribal traditions and reproduced through social practice. Yet the meanings of hospitality are flexible and may change as "hospitality practices are embedded into specific historical, socio-political and economic conditions" (Curro, 2014, p. 294). The shift from centrally-planned economies to a market economic system presents a marked change in these conditions and has resulted in transformed meanings of hospitality and associated practices. With the influx of (particularly Western) tourists locals gained new opportunities to engage in tourism entrepreneurship and thus to commodify hospitality. The paper will explore the use of homestay accommodation to re-invigorate local economies, provide livelihoods and counter depopulation.

\section{A brief history of Georgia during the transition 1990- 2010}

Georgia's transformation towards a market economy and its political orientation towards the West came along with political and social disturbances which included several civilian wars in parts of the country and the latest conflict with Russia about its influence in the strategic important region for the transportation of gas.

Already in the 1980 s with the permissive atmosphere of Gorbachev (Aydin, 2012) there had been movements in Georgia to protect nature and culture against the policies of the Soviet Union. This development ended in a bloody demonstration against the regime in 1989 and was followed by the first free Soviet elections in 1990 which were won by Gamsakhurdia who organized a successful referendum on independence from the Soviet Union in 1991 (Gumppenberg \& Steinbach, 2010).

\section{0-1992: Gamsakhurdia}

The relatively young state of Georgia under Gamsakhurdia faced typical problems of transformation countries. The political leadership was largely authoritarian and lacked the will to implement important reforms, which lead to a catastrophic economic situation accompanied by an anti-minority policy against Abhkazia and South Ossetia (Aydin, 2012). Many regional warlords followed their own agenda (Gumppenberg \& Steinbach, 2010) during the period when the Georgian presidency was vacant. 


\section{5- 2003: Shevardnadze}

After a coup d'état by the military and paramilitary groups in 1992, Georgia descended into civil wars (Tatum, 2009) and the presidency remained vacant. In 1995, with the termination of the civil war, Shevardnadze, the former foreign minister of the Soviet Union and then Speaker of the Georgian Parliament, became President of Georgia and a period of political stability began. Shevardnadze can be categorized as a typical postcommunist leader who wanted to keep the old communist order. Despite this stabilization, there was no free press in Georgia, reforms towards a market economy were not realised and the economic development of Georgia was affected by corruption and the activity of warlords in the periphery (Tatum, 2009). At the elections of 2000, it is argued that Shevardnadze only managed to win by strong manipulation (Gumppenberg \& Steinbach, 2010) and the disillusionment with current policies increased and eventually lead to the Rose Revolution in 2003. This opened the way for a stronger political and economic orientation towards the West. One of the main leaders of the protests was Michael Saakashvili, a politician with close ties to the USA and the EU, became the new president with $96 \%$ of the votes in 2004 (Gumppenberg \& Steinbach, 2010).

\section{4-2010: Saakashvili}

The new government embarked on economic reforms focussing on fighting corruption, taxes and customs, privatisation of state-owned assets and natural resources and changes to the labour market (Aydin, 2012). Control was also wrested over the regions controlled by warlords. In this time period, the transformation process was actively pursued, increasing the life standard of some of the population (Aydin 2012) with the result of creating a social gap between those benefitting from the economic reforms and those that did not. After all, the three leadership periods since 1991 appeared as 'fervently nationalistic; a quasi-continuation of the former communist regime; progressively neoliberal; and often as a hybrid of the three' (Tatum, 2009, p. 159). But the period of Saakashvili most strongly introduced the country's economy to neo-liberalism and the orientation towards the West (Özsoy, 2007; Gumppenberg \& Steinbach, 2010).

With this fast transformation and the political wish to join the EU and the NATO by the people of Georgia and their politicians, new conflicts emerged with the northern neighbour Russia. Because of a planned gas pipeline from the Caspian Sea to Western Europe by passing Russia, the Southern Caucasus became strategically important for the West. Yet, the Southern Caucasus was also seen by Russia as its sphere of influence (Asmus, 2010). Russia aimed to disrupt Georgia's orientation towards the West, by destabilising the regions of South Ossetia and Abchazia e.g. giving Russian passports to their inhabitants and fuelling already existing animosity between the different ethnic groups. This conflict resulted in the short war of South Ossetia in 2008 when Georgia lost control of South Ossetia and the region has been occupied by Russian military since (Gumppenberg \& Steinbach, 2010).

\section{Tourism in Georgia in the context of transformation}

These political and social developments had strong influences on the wider conditions for tourism development in Georgia and have shown that broader impacts on society and culture also need to be taken into account when analysing political-economic transitions and to understand tourism development in transformation regions. This contribution analyses the development of sustainable hiking tourism with the aid of western agencies and its consequences for Svaneti, a mountain region in the Great Caucasus in the Northwest of Georgia. To understand preconditions and the framework of this development it is important to also have an understanding of the meaning and importance of tourism for the socio-economic development of Georgia.

In Soviet times, the Soviet Republic of Georgia was referred as the 'Italy of the East' or as the 'Switzerland of the East'. These labels were based on the generally mild climate, the variations in landscapes and climates and the fruits and vegetables growing in the subtropical regions of Georgia. Georgia has been a kind of 'Eden' for Soviet society with the possibility to undertake a wide variety of activities such as mountaineering, beach 
vacations, hiking, spa vacation with sanatoriums, as well as cultural traditions such as its long tradition of wine cultivation (Steinmetzer, 2006; Gretschko, 1972; Salia, 1980). Tourism was centrally organised and most tourism took the form of mass tourism on the beaches of the Black sea and in the sanatoriums of the Spas e.g. in Borjomi. Georgia boasted around 152000 hotel beds before its independence in 1991 (Steinmetzer, 2006; Brade \& Piterski, 1994). A comparison with the supply of 248000 beds in the hotels in 2014 in Switzerland (BFS, 2014) (a country with a comparable size and an important history of tourism) demonstrates the economic importance of tourism in Georgia during the Soviet era. The early recognition of the importance of tourism to the socioeconomic development of Georgia led to one of the first Western investments during the 'Perestroika' era: the development of the Gudauri ski resort in the Great Caucasus in the 1980s with the support of knowledge transfer with actors from the Austrian tourism industry (Fussgänger, 1988). Yet, he emerging civil wars that came with the independence of Georgia resulted in an end of continued investment in the tourism infrastructure, which was then used to house the $300^{\prime} 000$ refugees within the country (Steinmetzer, 2006; Deubel 2009).
With the independence of Georgia in 1991, but especially with the revolution of 2003, the stable political context and the introduction of market economic principles, provided opportunities for new tourism development. In the last decade, this led to a different type of tourism development financed through private rather than state investments resulting in diversified tourism products. These tourism products were primarily targeted towards Western tourists (in line with the increasing political orientation towards Europe). Many of these new tourism developments were community-based and set in protected areas where traditional cultural landscapes meet the last wilderness areas with the highest biodiversity of Europe (WWF, 2014). Community-based tourism is often regarded as a great tool to support existing livelihoods and protect cultural and natural landscapes, while at the same time to establish new job opportunities in the peripheries (see Kühn, 1994; Mihalic \& Kaspar, 1996). Yet many studies point to the problem that an intensification of this kind of 'sustainable' tourism endangers the very resource it depends on (see for example Wheeller, 1991 and Williams \& Ponsford, 2009). In the course of this contribution, we will demonstrate, using the example

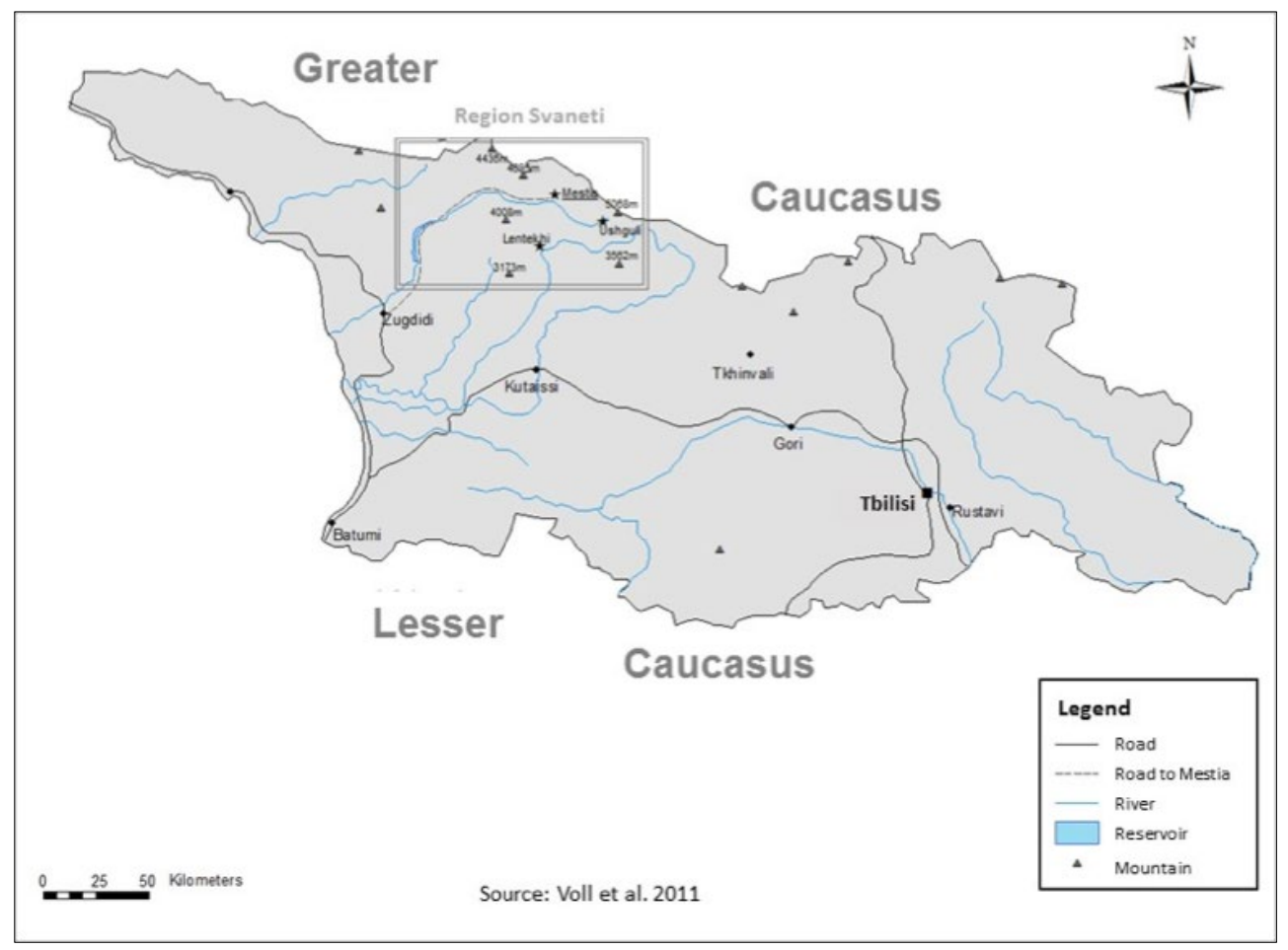

Figure 1: Map of Georgia and location of the region of Svaneti 
of Svaneti, that in the context of the transformation process of Georgia the development of communitybased tourism is also a question of power and education.

\section{Tourism in Svaneti}

The mountain region of Svaneti which is situated in the northwest of Georgia, is a peripheral region in the middle of the Great Caucasus and shares a common border with the Russian Republic (see Figure 1). There is no road connection into Svaneti from Russia, but mountain trails connect Svaneti with its northern neighbour. The region of Svaneti is attractive for the development of sustainable tourism, as it boasts several impressive mountain peaks above $5000 \mathrm{~m}$, glacier sand regions of wilderness containing some of the last virgin mountain forests of Europe. Svaneti is also well known for a high biodiversity of vegetation. Cultural attractions include the very old traditional cultural farming landscapesand historical stone towers (see Figure 2) built by families for defence against both external and internal aggression (blood feud was still practiced in peripheral regions of Georgia until recently) (Kvastiani et al., 2003; Gorshkov, 2010; Pro Mestia Georgien, 2010). These defensive towers have become a symbol of the region and were an important reason for classifying the Upper Svaneti as a UNESCO World Heritage site in 1996 due to "the distribution, form, and architecture of its human settlements" (UNESCO, 2015).

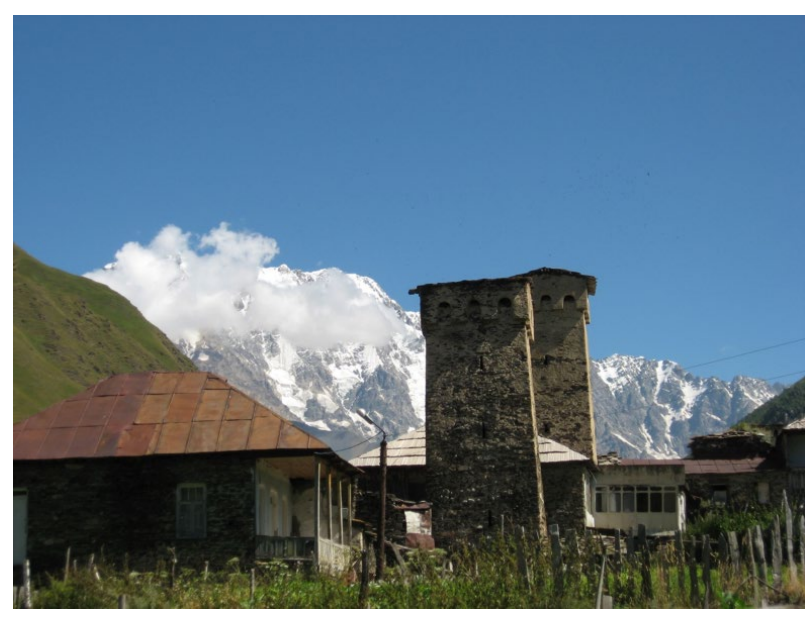

Figure 2: Traditional Defence Tower in Ushguli

The tourism history within Georgia highlights Svaneti as an important mountaineering region for the
Soviet Union when hikers and alpinists came over the passes from the north to practice mountain sports. One of the most difficult peaks to climb in the former territory of the Soviet Union was Mt. Ushba (located in Svaneti). With the independence of Georgia in the 1990s and the emerging civil wars within the country the borders to Russia were closed resulting in the end of hiking tourism in the region. Until the 2003 revolution in Georgia, the region was dominated by clan structures and suffered from considerable depopulation. Like many other peripheral regions in Georgia, Svaneti became a 'no go' area for tourists between independence and the 2003 revolution because of the activities of war lords (Kvastian et al., 2003; Interviews, 2010).

After the revolution in 2003, Svaneti experienced a fundamental change as the political framework was stabilised and the Central Government actively pursued reforms to introduce principles of market economy. With the orientation towards the West an instable democratization took place, but more importantly the corruption in the country was greatly reduced and new target markets for tourists emerged - Western Europe (Kvastiani et al., 2003). The political stability of Georgia is not a given, as tensions with Russia, due to the increasing alignment with the EU and NATO, may result in further conflict as seen with the short Georgian Russian war in South Ossetia in 2008. Yet Svaneti has since seen a steady rise in number of tourists from the European Union, the USA and Israel, and newspaper articles marketing the trekking opportunities in Western newspapers (e.g. Eshelby, 2008; Neubronner, 2009).

This dynamic political context has had different impacts on tourism in Svaneti and therefore on the livelihoods of the local population and the associated cultural landscapes. Many of the rural villages in Svaneti are very difficult to reach (only by four wheel drive in the summer) and are dependent on political decisions taken by the state government. There is potential for the further development of tourism in Svaneti, as it does not market its traditions and tribal cultures as much as other Georgian regions. Yet it is important to recognise that the development of tourism leads to changing relationships between the periphery and the central government. The following section will outline the methods used for the exploratory research project before turning to 
a discussion of the impacts of the political-economic changes on tourism and socio-economic practices in Svaneti.

\section{Methods}

During a scientific field trip in Georgia with 30 persons including Geography students and lecturers in 2010, an exploratory study of nature-based tourism initiatives was undertaken in the region of Svaneti (Voll et al., 2011). The aim of the research was to identify opportunities and barriers to the development of naturebased tourism in the hiking region. Semi-structured interviews were held with different stakeholders in the region. These stakeholders were representatives from the community tourism initiatives, tourism producers, farmers, mountain guides and teachers in the villages. As the interviews took place in a region where tribal norms and cultural traditions still play a fundamental role, it was important to first choose stakeholders who have a historical and broader understanding of tourism developments for the interpretation of events, second to also interview farmers and suppliers below the management level and third to reflect all the results of the interviews in the context of the dynamic history of the region. That is why in addition to the interviews, the research group employed a short-term, mobile ethnography of the tourism producers in the region (Büscher \& Urry, 2009; Knoblauch, 2005; Jackson 2006). Participant observations were undertaken by the research participants in their respective accommodation (basic homestays) in the four villages visited along the horseback trail between Mestia and Ushguli (Mestia, Adishi, Iprali, Ushguli). The research participants discussed their observations every evening and used these as bases for the interviews.

In a first step, the research group tried to understand the implementation process of a community based tourism project in Svaneti. This project was initiated in 2005 by the NGO Georgian Union of Mountain Activists (GUMA) and had been supported by the following western aid agencies and foundations Friedrich Ebert Stiftung (Germany), Swiss Development and Cooperation Agency (SDC) and USAID. The aim was to create community based tourism products in collaboration with
30 families in six communities of Upper Svaneti and in the Mountain-Tourism Center of Upper Svaneti (SMTC) in Mestia. In the second step, the occupancy of houses in the village of Ushguli (arguably the highest village of Europe) was mapped according to the following labels: unoccupied, agriculture and agritourism and second homes in order to gain a deeper understanding of the processes initiated by these western actors and the GUMA and to check the results from the interviews in Upper Svaneti. To determine how tourism led to new occupancy in the village, the conditions of the gardens were used as proxy for the type of occupancy. After an instruction by locals, the level of occupation of the houses in the village were judged. The properties of unoccupied houses did not contain tended gardens (such as lawns, vegetable patch or domestic livestock or pets). Locals stated that only families who live during longer time periods in the village had animals and crop plants in their gardens, as the transport route into the village of Ushguli is often cut off. In comparison, the properties of second homes do not tend to be used for purposes of self-sufficiency, as the owners do not visit often enough to care for vegetables or livestock. As there is a level of ambiguity in distinguishing between second homes and permanent residency, during the mapping just two classifications were mapped: occupied (living/ farming) and unoccupied buildings. The differentiation of second home and residential buildings then played a role when connecting these results with tourism development. Following the results of the interviews all families with permanent residency in Ushguli also offer beds for guests. Therefore all houses with strong agriculture characteristics were classified as tourism use even though they had no signs. All other occupied houses were only classified for tourism purpose if they had signs which indicated tourism offers (homestays, cafes, shops, bars etc.) posted on the houses. Interviews indicated a close connection between tourism development and the reuse or renovation of buildings. 


\section{Results}

\section{Developments in Svaneti 2003 - 2010}

After the stabilization of the region in 2003 , initiatives from outside the region were instrumental in using the cultural and natural heritage of the region as attraction for the development of tourism and the protection of cultural heritage. The WWF was engaging in the overall region of the Caucasus, on the one hand, to prevent the destruction of wilderness areas due to logging and hunting and non-sustainable developments and, on the other hand, to counter rural depopulation and thus preserve the important cultural landscapes (Interviews, 2010; WWF, 2014). Another protagonist in the region was Pro Mestia (also externally financed). Pro Mestia concentrated on the conservation of the cultural heritage but was also involved in tourism projects (Pro Mestia Georgien, 2010). American (USAID), German (Friedrich Ebert Stiftung) and Swiss (Swiss Development and Cooperation Agency) agencies supported communitybased tourism projects, specifically in Svaneti, with the aim to develop tourism based on the cultural and natural resources of the region. In addition, the Centre of 'Svanetitrekking' was founded in 2006 in collaboration with the Georgian Union of Mountain Activists in order to provide an information point for tourists and to sell tourism packages (see Svanetitrekking, 2014). Basic infrastructures have been seen as an advantage and tourism products were based on the existing local possibilities rather than on investments from outside.

New tourism products (such as organized hikes with mountain guides, baggage transport with horses and overnight stays in the periphery in homestays) were developed in order to offer new possibilities for locals to earn their livelihoods and counter depopulation. The limited accessibility has been seen as a chance as it forced tourists to stay overnight in the villages and created further opportunities for the local population to sell locally-made products. The target markets were trekking and adventure tourists from the West who do not expect too much comfort and are more interested in the personal engagement with the local population. The ideas of this kind of trekking tourism to support regions with weak economies without too much external interference was successfully implemented in the Piedmont valleys of the Alps (see Vogt, 2012; Vogt, 2008) and the contact and engagement with the local host population is more important than highly commodified consumption (see Maurer et al., 1992). Even though the initiative came from external organisations and therefore cannot per se be called a bottom-up process, the implementation was undertaken in close collaboration with and integration of the locals in the decision-making process (Interviews, 2010).

The new notion of individual entrepreneurship (i.e. the adaptation to the market economy) was important for a successful implementation of the project (Interviews, 2010). Families struggling with the concept of individual entrepreneurship and the commodification of hospitality (even at a rather low level) had to grapple with a mentality of state entrepreneurship formed during the socialist era and with the shift from the traditional values of hospitality (highly regarded in Georgian culture) towards selling hospitality which runs counter to the notion of being hospitable to strangers in all circumstances. The social relations of many communities are still regulated by values and norms which are defined by the community itself rather than by modern state systems. Yet, although these decisions are binding for the entire community, it is difficult to discern the actual process of decision-making as it can either follow a democratic process or decisions can be taken by important personalities as informal representatives of the community. These circumstances rally contest individual entrepreneurship as decisions are traditionally made by the community and not by an individual (Interviews, 2010). It mirrors the fast transformation from historical systems of common to a neoliberal understanding of individual entrepreneurship and success within less than one generation. With the increasing success of the project more and more families opened their homes to tourists, necessitating a solution to the problem of envy amongst the community.

E.g. the arrival of the research group of 30 people in one village led to an aggressive discussion among the inhabitants who could host how many of the arriving guests. It is arguable if this behaviour results from a traditional understanding of hospitality or the new emerging economic occurrences of new income possibilities when traditional social contexts are 
transferred into neoliberal social contexts. It seems that an increasingly commodified understanding of hospitality also raises new tensions in the existing livelihoods of the inhabitants. All these new entrepreneurial values contested the traditional economic values of communal entrepreneurship and cultural values of hospitality, especially in the regions predominantly based on religious and 'tribal' norms (Curro, 2014; Interviews, 2010).

To assist families and communities in this transformation process, Svanetitrekking in partnership with the aid agencies from abroad, offered seminars, teaching local family enterprises and supporting professionalism (e.g. internet appearances). It was an important policy for the initiative to support this transformation by respecting the local traditions and cultures and to have a tourism product which is possibly more appropriate for the local context and at the same time supports the continued existence of livelihoods in the region (Interviews, 2010). It was therefore not possible to leave the choice of accommodation to the tourists. In the tourism package of Svanetitrekking, it was important to leave the decision to the communities where the tourist of a specific group would stay that night, to minimize envy in the villages and to respect traditional systems of community decisions (Interviews, 2010).

\section{Exploratory study Ushguli}

Ushguli was the first village in the periphery of Svaneti which developed tourism. The popularity of this community among tourists rose significant because Ushguli became advertised by Svanetitrekking as the highest community in Europe, because it is the starting point for hikes to the highest peak of Georgia, Mt. Shkara $(5193 \mathrm{~m})$ and because it offers many of the old world heritage defence towers and antique works of art. Although it is arguably the highest community in Europe and an important base for mountaineering and hiking, Ushguli has experienced a significant population decline in the last decades (although no population statistics are available), also because of its difficult access. Depopulation has led to a rapid increase of ruins, as houses rapidly collapse in winter if the large quantity of snow is not removed from the roofs.

The main aim of the international NGOs is to stop and reverse depopulation of peripheral areas by creating new business opportunities by implementing community-based tourism projects based on natural and cultural resources (Binns \& Nel, 2002; Ashley et al., 2001; Vogt, 2012). Local interviewees pointed out that because of the success of these new tourism developments families are coming back from the cities and reinvesting in their buildings. As the community of Ushguli consists of three different sections and it is the middle and upper sections which are mainly used for tourism - as they have more beautiful surroundings - it was interesting to find out in which way this tourism initiative helped the community to counter depopulation and the accompanying abandonment of houses. To better understand the effects of this initiatives on the local population, the occupancy of the buildings in the village

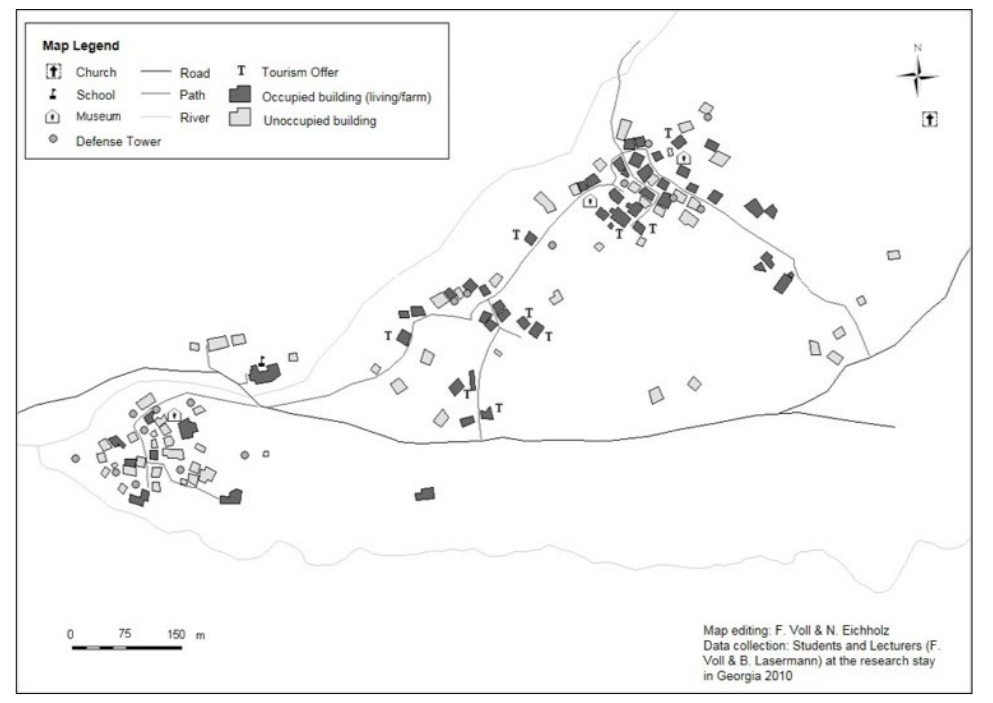

Figure 3: Map of Ushguli and the occupancy of the houses 
of Ushguli was mapped. As described in the methods, this was achieved by a mapping exercise and the categorization of buildings in unoccupied and occupied and agritourism/tourism use based on the conditions of the gardens (see Figure 3).

The results of the mapping exercise show that 38 of the 46 existing buildings in the lower part of Ushguli were unoccupied (this included ruins). In contrast, the middle and upper part of Ushguli consisted of 50 occupied buildings out of 96 buildings and nine different tourism offers. These findings indicate that there may be a connection between tourism development and halting depopulation. As indicated in the interviews and the mapping, the proportion of the occupied or even re-occupied buildings to unoccupied buildings was much higher in the upper section of the village where community based tourism had developed in the last years. The reason for the location of tourism accommodation in the middle and upper part is due to the proximity to the starting point of the hiking tours to Mount Shkara and the nice view from the upper part of the village (see Figure 2). The high number of homestay tourism offers and occupied buildings in this part not only shows the economic impact of the community based tourism project in Ushguli, but also the impact on the cultural heritage and understanding: As several occupied buildings are often used by one family, single buildings may be part of a wider system of buildings used for different purposes by one family. The number of only nine tourism offers in the middle and upper part of the village therefore led to the occupancy and protection of almost half of the buildings. For the locals it was also important that this heritage could be saved and they were proud to showcase their traditional values to tourists from Georgia and abroad and to convey their understanding of regional history (which is in danger of being forgotten due to depopulation) and transformation processes (Interviews, 2010).

\section{Recent developments in Svaneti}

The interviews in different villages of Svaneti and the exploratory study in Svaneti showed that throughout the community based tourism initiative new economic developments emerged and therefore depopulation could be prevented and in some cases reversed. Although some of the historical buildings could be saved, some locals have warned of the potential negative effect of rising tourist numbers due to new (road) infrastructure and external investment in combination with a lack of local control on the continued existence of traditional livelihoods and their culture (Interviews, 2010). Whereas others believe that tourism offers the only opportunity for locals to make a living (Interviews, 2010). These different points of view differ in their assessment of community resilience. The question that will decide the future of these communities is whether they will be able to adapt to highly commodified tourism while at the same time protect their livelihoods, traditions and cultures. The example of Mestia, the capital of the district of Svaneti, shows that the new challenge was already on its way in 2010: A lot of construction took place already during the field work period. Some of the roads into the more peripheral regions were tarmacked, a new regional airport was built and some of the houses in the centre (former Soviet buildings in ruins for several years) were reconstructed. While some inhabitants of Mestia supported the rejuvenation of the city centre, they were dismayed at the lack of opportunities for inhabitants to participate in decision-making. They also criticized that almost all the investment was provided from outside the community (the central government or external investors with the help of the World Bank) (Interviews, 2010). Many would have preferred to invest in the protection of their heritage (the UNSECO World heritage towers) instead of investing in new hotel infrastructures which challenged the communitybased tourism projects. They were scared of losing the authenticity of their community based and regional organized tourism offers (Interviews, 2010). These fears and uncertainty demonstrates the long-term success of community-based tourism, which is often dependent on regional, national and international political economic choices. Particularly local communities with weak levels of resilience (e.g. due to lacking skills and knowledge or political power) are dependent on decisions taken elsewhere, making it difficult to implement communitybased tourism projects as external influences may render the chosen strategy ineffective.

Retrospectively, large-scale investment projects 
of the central government changed the landscape of Mestia, a development which had been predicted by critics during the field work in 2010. A new ski resort was developed and a new highway linking Mestia and Central Georgia was built allowing increasing numbers of tourists to come to the area. The construction of expensive structures with the help of star architects from the west (albeit with symbolic references to the traditional defence towers) are an indication of the type of development the government of Georgia is pursuing.

These developments run counter to the aims of the original community-based tourism project and may challenge the continued success of alternative tourism in the region. They especially contest traditional understandings of hospitality in the regions. It is highly questionable if this commodified tourism according to distinctive neoliberal interpretations of 'selling' hospitality provides opportunities for the local population to adapt their traditional understanding of 'giving' hospitality in a self-determined way.

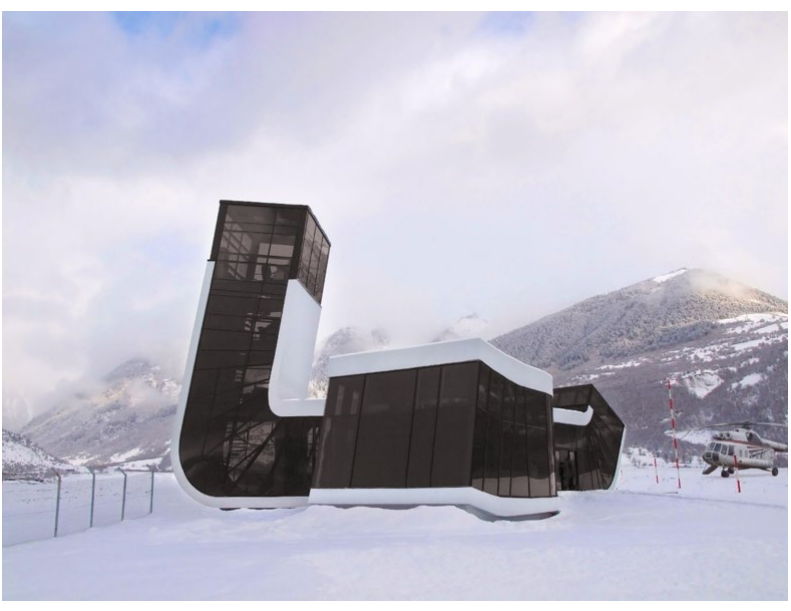

Figure 4: The Queen Tamar Airport in Mestia, (C) J.Mayer H. und Partner, Photo: Jesko M. Johnsson-Zahn

\section{Conclusions}

The results from the exploratory research demonstrate how tourism may be a driver of socioeconomic change in a society with wide-ranging impacts. The decision which type of tourism to develop and at what intensity is essentially a question of power and governance.

The development of the region to this day reveals the problem that community-based tourism, which

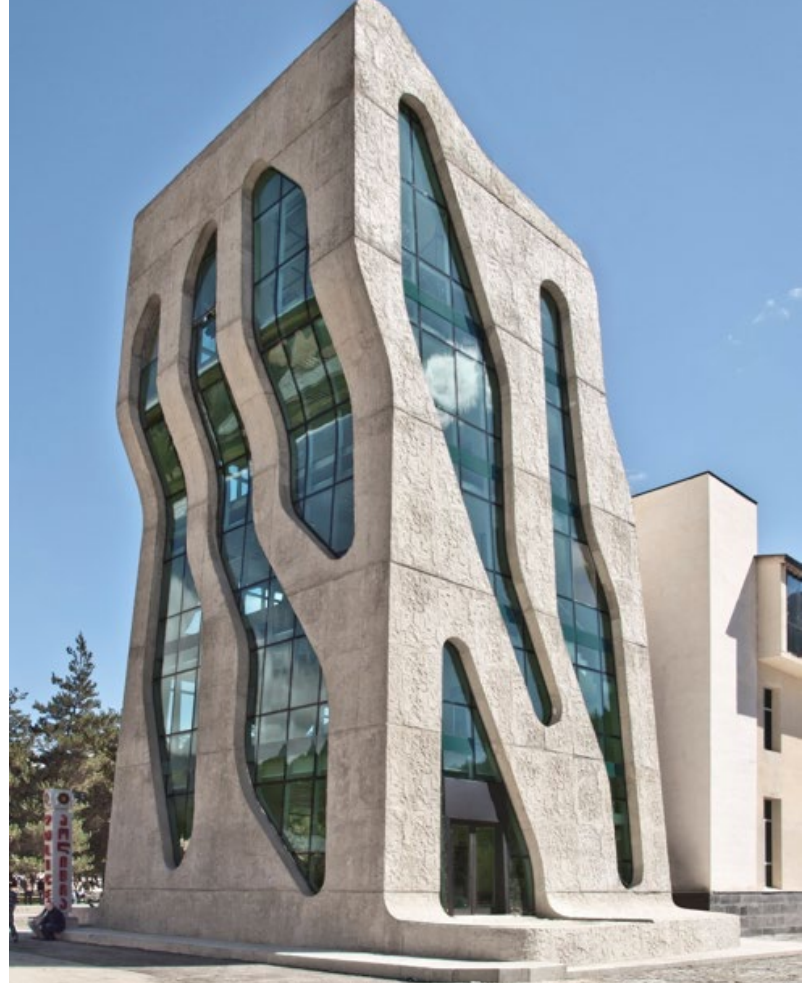

Figure 5: Police Station in Mestia

C J.Mayer H. und Partner, Photo: Jesko M. Johnsson-Zahn

already contested the resilience of the local population and livelihoods, is challenged by external investment in a different type of tourism which disturbs the difficult equilibrium between individual entrepreneurship (here in the form of external investment) and communal interests. In Svaneti, the introduction of the concept of individual entrepreneurship has led to the increasing commodification of hospitality with the negative result that it is more difficult for guests to engage with local traditions and heritage. In contrast, the community-based tourism project positions local cultures, as constituted by norms and practices, as the central experience for the guests. The question remains whether alternative types of tourism can co-exist and survive with the development of new institutional frameworks geared towards a different type of political economy which results in tourism developments with a level of quality and comfort which cannot be provided by local individual homestay entrepreneurs. The example of Svaneti is not the only one in Georgia where the initial success of regional tourism initiatives is assumed as a development strategy by the government, yet transformed into public- 
private developments driven by external investors. It remains to be seen whether this is typical of other transformation countries of the former Soviet Union, as these democracies are young and power tends to be focussed in the hands of few. This exploratory study only managed to provide a superficial analysis of the politicaleconomic situation of tourism development in Svaneti and its implications for community-based tourism. More in-depth research is necessary that analyses: a) the meanings of hospitality in a neoliberal political economy and changes to local cultures (in particular values of 'giving' hospitality), b) the distinct entrepreneurial cultures emerging from new institutional and politicaleconomic constellations and c) the 'new landscape of governance' (Mosedale, 2014, p. 60), particularly as different actors and levels of scale become involved. Longitudinal studies would contribute greatly to the understanding of transformation and would allow for the analysis of transitional evolutions (e.g. institutional, cultural, political-economic). The findings would have implications beyond post-socialist countries and would benefit other types of social transitions.

\section{REFERENCES}

Ashley, C., Roe, D. \& Goodwin, H. (2001). Pro-poor tourism strategies: Making tourism work for the poor: A review of experience. Nottingham: Overseas Development Institute

Asmus, R. (2010). A little war that shook the world: Georgia, Russia and the future of the West. Basingstoke and New York: Macmillan.

Aydin, G. (2012). Economic Change and Development in Georgia after the Rose Revolution: A Boost to the Mikheil Saakashvili's Consolidation of Authority. Uluslararası Yönetim Iktisat ve Işsletme Dergisi, 7(14), 35-50.

BFS - Bundesamt für Statistik (2014): Hotellerie: Angebot und Nachfrage der geöffneten Betriebe im Überblick. Retrieved from <http://www.bfs.admin.ch/bfs/portal/de/index/themen/10/03/ blank/key/01/01.html> on 21.10.2014.

Binns, T., \& Nel, E. (2002). Tourism as a local development strategy in South Africa. The Geographical Journal, 168(3), 235-247.

Brade, I., \& Piterski, D. (1994). Die Kaukasischen Mineralbäder. Möglichkeiten und Grenzen der Entwicklung einer Tourismusregion. Europa Regional 4(2), 10-19.

Büscher, M., \& Urry, J. (2009). Mobile methods and the empirical. European Journal of Social Theory, 12(1), 99-116.
Curro, C. (2014). A 'Gift from God'? Georgian hospitality between tradition and pragmatism. Hospitality \& Society (4)3, 293-310.

Deubel, M. (2009). Kreuzfahrttourismus auf dem Schwarzen Meer - Eine Analyse mit regionalem Fokus auf die georgische Küste. Unveröffentlichte Diplomarbeit am Institut für Geographie Trier.

Eshelby, K. (2008). Raise a glass to life's simple pleasures. The Observer (02.11.2008).

Fußgänger, H. (1988). UdSSR: Schnee von morgen. Die Zeit Nr. 32 (05.8.1988).

Gorshkov, M. (2010). Swaneti - Das Land der tausend Türme und Gletscher. Retrieved from http://swaneti.de/Svaneti\%20 Kaukasus\%20Georgien\%20l.htm on 20.10.2010.

Gretschko, A. (1972). Die Schlacht um den Kaukasus. Berlin: Deutscher Militärverlag

Gumppenberg, M. C. V. \& Steinbach, U. (2010). Der Kaukasus. Geschichte - Kultur-Politik. München: C.H.Beck

Hall, D. (1991). Tourism and Economic Development in Eastern Europe and the Soviet Union. London: Belhaven Press

Hall, D. (1998). Central and Eastern Europe. In: Williams, A.M. and Shaw, G. (eds) Tourism and Economic Development in Europe. (pp. 345-373). Chichester, Uk: John Wiley \& Sons.

Hall, D. (2000). Tourism as sustainable development? The Albanian experience of 'transition'. International Journal of Tourism Research 2(1), 31-46.

Hall, D. R. (2004). Tourism and transition: governance, transformation, and development. CABI.

Interviews 2010: Interviews with local population and tourism actors in Svaneti during a scientific field trip in 2010. (made for internal scientific purposes)

Jaakson, R. (1996). Tourism in Transition in Post-Soviet Estonia. Annals of Tourism Research, 23(3), 617-634.

Jackson, J. (2006). Ethnographic pedagogy and evaluation in short-term study abroad. Languages for intercultural communication and education, 12, 134.

Knoblauch, H. (2005). Focused ethnography. In Forum Qualitative Sozialforschung/Forum. Qualitative Social Research, 6(3).

Kornai, J. (1992). The affinity between ownership and coordination mechanisms: the common experience of reform in socialist countries. In K.Z. Poznanski (Ed.) Constructing Capitalism: The Re-emergence of Civil Society and Liberal Economy in the PostCommunist World. (pp. 97-116). Boulder, Colorado: Westview.

Kühn, M. (1994). Fremdenverkehr und regionale Entwicklung. Kassel: Universität Kassel

Kvastiani, T., Spolanski, V., \& Sternfeldt, A. (2003). Georgien entdecken. Berlin: Trescher 
Light, D., \& Dumbrăveanu, D. (1999). Romanian Tourism in the PostCommunist Period. Annals of Tourism Research, 26(4), 898-927.

Maurer, M., Adamaschek, H., \& Brözel, C. (1992). Tourismus und Dritte Welt. Bern: Forschungsinstitut für Freizeit und Tourismus (FIF), Universität Bern

Mihalic, T., \& Kaspar, C. (1996). Umweltökonomie im Tourismus. Bern: Paul Haupt

Mosedale, J. (2006). Tourism commodity chains: market entry and its effects on St Lucia. Current Issues in Tourism, 9(4-5), 436-458.

Mosedale, J. (2011). Diverse Economies and Alternative Economic Practices in Tourism. In N. Morgan, I. Ateljevic \& Pritchard, A. (Eds) The Critical Turn in Tourism Studies: Creating an Academy of Hope. (pp. 194-207). London and New York: Routledge.

Mosedale, J. (2014). Political Economy of Tourism: Regulation Theory, Institutions and Governance Networks. In C.M. Hall, A.A. Lew \& Williams, A.M. (Eds) The Wiley-Blackwell Companion to Tourism. (pp. 55-65). Oxford, UK: John Wiley \& Sons, Ltd.

Neubronner, E. (2009). Swanetien - ein noch unbekanntes TrekkingDorado. Neue Züricher Zeitung Nr. 246 (23.10. 2009).

Özsoy, I. (2007). Human transformation in the transition economies: the case of Georgia. Journal of East-West Business, 12(4), 71-103.

Pro Mestia Georgien (2010). Pro Mestia. Retrieved from http://www. promestia.info/index. php?id=23> on 20.10.2010.

Salia, K. (1980). Histoire de la Nation Géorgienne. Paris: ed. N. Salia

Smith, A., \& Stenning, A. (2006). Beyond household economies: articulations and spaces of economic practice in postsocialism. Progress in Human Geography, 30(2), 190-213.

Stark, D., \& Bruszt, L. (1998). Postsocialist pathways: Transforming politics and property in East Central Europe. Cambridge University Press.

Steinmetzer, K. (2006). Tourismus in Georgien. Entwicklung und Herausforderungen. Geographische Rundschau, 58(3), 37-43.

Stoica, C. A. (2004). From good communists to even better capitalists? Entrepreneurial pathways in post-socialist Romania. East European Politics \& Societies, 18(2), 236-277.

Svanetitrekking (2014). About us. Retrieved from http://www. svanetitrekking.ge/eng/about.htm on 22.10.2014.

Tatum, J. D. (2009). Democratic transition in Georgia: Post-Rose Revolution internal pressures on leadership. Caucasian Review of International Affairs, 3(2), 156-171.

Tickle, A. (2000). Regulating environmental space in socialist and postsocialist systems: nature and landscape conservation in the Czech Republic. Journal of European Area Studies, 8(1), 57-78.

UNESCO World Heritage Centre (2015): Upper Svaneti. http://whc. unesco.org/en/list/709 13.01.2015.
Vogt, L. (2008). Regionalentwicklung peripherer Räume mit Tourismus? Eine akteursorientierte Untersuchung am Beispiel des Trekkingprojekts Grande Traversata delle Alpi. Erlanger Geographische Arbeiten, Special Issue No. 38. Erlangen.

Vogt, L. (2012). Dezentrale Tourismusprojekte als Chance für periphere Alpenregionen? In Fassmann, H. \& Glade, T.H. (Hg.) Geographie für eine Welt im Wandel. 57. (pp. 189-203). Deutscher Geographentag 2009 in Wien. Göttingen.

Voll, F., Eichholz, N., \& Riedmann, V. (2011). Sustainable eco-tourism in Georgia. Recent tourism developments in the Caucasus in the example of the Svaneti mountain region. Natur und Mensch. Jahresmitteilungen der Naturhistorischen Gesellschaft Nürnberg 2010, 47-60.

Wheeller, B. (1991). Tourism's troubled times: Responsible tourism is not the answer. Tourism Management, 12(2), 91-96.

Williams, A. M., \& Baláž, V. (2000). Tourism in transition: economic change in Central Europe. London: IB Tauris.

Williams, A. M., \& Baláž, V. (2001). From collective provision to commodification of tourism? Annals of Tourism Research, 28(1), 27-49.

Williams, A. M., \& Baláž, V. (2002). The Czech and Slovak Republics: conceptual issues in the economic analysis of tourism in transition. Tourism Management, 23(1), 37-45.

Williams, P. W., \& Ponsford, I. F. (2009). Confronting tourism's environmental paradox: Transitioning for sustainable tourism. Futures, 41(6), 396-404.

Worthington, B. (2001). Riding the ' $J$ ' Curve: Tourism and Successful Transition in Estonia?, Post-Communist Economies, 13(3), 389400 .

WWF (2014). Kaukasus. Zentrum der Artenvielfalt. Retrieved from http://www.wwf.de/themen-projekte/projektregionen/ kaukasus/zustand-und-bedeutung on 22.10.2014.

Wyrwich, M. (2012). Regional Entrepreneurial Heritage in a socialist and a postsocialist economy. Economic Geography, 88(4), 423445.

Datum prijave rada: 23.04 .2015

Datum prihvatanja rada: 30.04.2015.

\section{Kontakt}

Frieder Voll, University of Applied Sciences HTW Chur, Pulvermühlestrasse 57, 7000 Chu, Switzerland

E-mail: frieder.voll@htwchur.ch

Jan Mosedale, University of Applied Sciences HTW Chur, Pulvermühlestrasse 57, 7000 Chu, Switzerland

E-mail: jan.mosedale@htwchur.ch 